\title{
Determinants of Participation in Contract Farming Among Smallholder Dairy Farmers: The Case of North Shewa Zone of Oromia National Regional State, Ethiopia
}

\author{
Mosisa Hirpesa $^{1}$, Belaineh Legesse ${ }^{1}$, Jema Haji ${ }^{1}$ \& Ketema Bekele ${ }^{1}$ \\ ${ }^{1}$ School of Agricultural Economics and Agribusiness, Haramaya University, Dire Dawa, Ethiopia \\ Correspondence: Mosisa Hirpesa, School of Agricultural Economics and Agribusiness, Haramaya University, \\ Dire Dawa, Ethiopia. E-mail: mossblessed2015@gmail.com
}

Received: February 13, 2020

Accepted: March 4, 2020 Online Published: November 14, 2020

doi:10.5539/sar.v10n1p10

URL: https://doi.org/10.5539/sar.v10n1p10

\begin{abstract}
The study analyzed the determinants of participation in dairy contract farming using data collected from 424 (192 participants and 232 non-participants) randomly selected milk-producing farmers from three districts of the North Shewa Zone of Oromia Regional State, Ethiopia. The study combines both quantitative and qualitative data obtained from household interview using semi structured questionnaire, key informant interview, focus group discussion, and direct personal observation. Descriptive statistics and econometric models were used to analyze data. The binary logistic regression model was employed to identify factors affecting participation in dairy contract farming. Results show that age, sex, perception of price uncertainty, frequency of extension contact and access to training significantly and positively affect participation in dairy contract farming while time taken to milk collection centers affected it significantly and negatively. Results suggest that the need to encourage young farmers, female-headed households, increasing frequency of extension contact, creating access for training, decentralization of milk collection centers and contract farming reduces perceived price uncertainty faced by smallholder farmers from the spot market through creating guaranteed milk price in the study area.
\end{abstract}

Keywords: dairy contract farming, logistic regression, North Shewa Zone, Oromia, Ethiopia

\section{Introduction}

Recent sophisticated ideas like environmentally soundness (which concerns the interaction between the environment and economics) and sustainability (which adds a broad social element to the environmental and economic, and requires the consideration of time horizons), standards and regulations related to environment and health care among the driving forces of the fast growing contractual relationships (Rehber, 2019). The process of globalization and market liberalization in many developing countries has resulted in the growing integration of global agricultural markets and major structural change in the agriculture sector. The processes have expanded lucrative markets for high-value agricultural products (Seerp et al., 2018).

In developed countries, contract farming plays a significant role (Hanisch and Rommel, 2012; MacDonald and Korb, 2013; Rehber, 2019). Various researches conducted in developing countries have also yielded similar results (Brüntrup and Peltzer, 2007; UNCTAD, 2009; 2011). Studies also show that contract farming is potentially beneficial than independent production (Coastales et al., 2008; Birthal et al., 2008; Bolwig, 2012; Adjognon, 2012). Access to new reliable markets, ability to purchase inputs, protection against the systematic loss, access to credit and financial intermediation, access to information, production and management of skill transfer, new technology, agro-services (mechanization, transportation), ability to receive inputs (seeds, fertilizers) at lower cost and extension services, risk reduction through guaranteed prices, decrease transaction cost and training for management are among the advantages of participating in contract farming. Contrary to this, risk of contract default, risk of monoculture, little or lack of bargaining power, monopsonistic markets, corruption, delays in payment, change in contract terms, loss of flexibility, promotion of export-orientated agriculture at the expense of subsistence agriculture and favoring large-scale farmers, etc. are the main disadvantages for smallholder farmers (Seerp, 2018).

Looking in to the experiences of developed and developing countries and customizing contract farming into the contexts of Ethiopia will certainly benefit both participants and non-participants. This might give a room to solve 
the problem that the country faces and might provide the way out for the smooth functioning of the economy, in general. Even though contract farming is at its early stage, in Ethiopia, farmers engaged in sesame, passion fruit, green beans, vegetables, coffee, malt barley, chickpea, seed potatoes, bamboo, sugar cane, flowers and milk have experiences in contract farming (Birhanu, 2016; Holtland, 2017). The informal milk market constitutes above 80\% of marketed milk in east Africa (Burundi, Ethiopia, Kenya, Rwanda, Tanzania, and Uganda) (Makoni et al., 2013). Similarly, Shapiro et al., (2017) reported only $19 \%$ of cow milk entered into the milk value chain in Ethiopia out of the 5.2 billion liters produced annually. But, local production does not satisfy growing local demands due to increased population growth over the past decades. Between 2013 and 2017, the country spent over 48.61 million US dollars to import milk and various milk products. This indicates that the country is a net importer of milk and its derivatives. That means, the government forced to import dairy products through increasing foreign currency spending and this creates difficulty in the smooth functioning of the economy of the country (Assefa 2019).

Individually, a small-scale producer has a tiny marketable surplus and, on the other hand, local markets are thin and trading in distant urban markets is uneconomical due to high costs of marketing (Birthal et al., 2005). That means dairy producers face high logistics costs arising from poor storage and transport and undeveloped collection and cold chain logistics. For the most part, milk collection, chilling and transport are not well organized. Transaction costs are high and up to $20-35 \%$ of milk output is spoiled or otherwise lost (SNV, 2010). Yet, milk processors in Ethiopia operate only at $18-43 \%$ of the capacity level. This means milk processors; operate under capacity whereas smallholders consume their production at the household level (AGP-LMD, 2013b). Milk need to be sold immediately or converted into less perishable forms to avoid post-harvest losses. In the study area, smallholder dairy producers transport milk to the processors (collection centers) walking on foot for long hours. This is because of limited milk collection points, lack of transportation, lack of chilling equipment, lack of coordination on the collection of milk, and lack of sufficient feed supply. The overall effects of the above factors reduce the participation of dairy producers in the study area (NSZPEDO, 2019).

One of the major problems that affect the performance of milk processors in our country is the problem of finance. Currently, there is no Ethiopian company processing powdered milk, although some processors are planning to invest in such facilities. Recently Anchor, New Zealand's leading milk brand has begun producing fortified milk drink in Ethiopia with a quick gain of market share (Assefa, 2019). While most of the milk produced and supplied by smallholder farmers is fresh milk excluding the evening milk $(50 \%$ of total production). The majority of farmers in the study area process the evening milk into butter and cheese (Ayib) due to lack of market and proper storage utensils. Only a few of the households keep evening milk in cold material and supply to the milk collectors/traders in the next morning. Butter and cheese are usually sold to individual traders or individual customers in nearby markets. Farmers are often uncertain about price because milk prices changes depending on prevailing market conditions in the study area (NSZPEDO, 2019).

In the study area, the contract is a type of market specification contract only supported by creating access to buy input (like molasses and beer factory by-product, etc.) for smallholder farmers. The transaction between farmers and milk collectors/traders/processing firms is based on an agreement specifying the product to be supplied, quality attributes, time and location of delivery. Such a contract is more applicable in a situation where there is a need for market coordination and the buyer is not concerned about production methods, other than product quality to be measured at collection. This type of contract may be informal or formal. Under this contract, the farmer retains full control of all management decisions so that he/she bears most of the production risk on his/her own. Contracting farmers still complain about the price of milk per liter they received from collectors in the study area. They complain by relating the price of milk they received being nearly equal to a liter of bottled water or natural purified water.

The market is the lifeblood of smallholder farmers and also one of the major challenges in developing countries to continue production or to stop. A farmer's decision to participate in contract farming is affected by different physical, social and economic factors. The main buyers of milk from smallholder farmers in the study area are local collectors/traders, milk processing companies like Mama, Shola, Elemtu, and family, cooperative unions, cafes, and individual consumers. Farmers enter into different forms of contract (i.e. milk producers contracting with traders, milk producers contracting with private processing company or cooperative, etc.) whenever they think profitable. Therefore, formal or informal agreements are the way of creating a market for smallholder farmers to supply raw milk to the processors. Empirical analysis of the determinants of dairy contract participation gives us room to develop strategies and policies that improve the milk market specifically and the dairy sector in general. Thus, the motivation of the present study is to turn the eyes of different stakeholders to focuses on the means of increasing the role of dairy sub-sector to the local and countrywide economies by 
understanding the constraints of participation in dairy contract farming that needs to be tackled.

\section{Research Methodology}

\subsection{Description of the Study Area}

North Shewa zone is one of the 20 zones in Oromia National Regional State and the nearest zone to the capital city, Addis Ababa, next to Oromia's special zone. North Shewa zone lies between $9^{0} 05^{\prime \prime}$ ' $\mathrm{N}$ and $10^{\circ} 23^{\prime \prime} \mathrm{N}$ latitude and $37^{\circ} 57^{\prime \prime} \mathrm{E}$ and $39^{\circ} 28^{\prime \prime} \mathrm{E}$ longitude. The total area under this zone is $8,989.8 \mathrm{~km}^{2}$. It constitutes about $2.5 \%$ of the total area of Oromia National Regional State. It is divided into tropical (20.7\%), sub-tropical (42.6\%) and temperate $(36.7 \%)$ respectively. The zone falls between 500 and 3541 meters altitude above sea level. The mean annual rainfall ranges between $600-2000 \mathrm{~mm}$, while the mean annual temperature ranges between $10^{\circ} \mathrm{C}-25^{\circ} \mathrm{C}$. About $51 \%, 32.5 \%$ and $16.5 \%$ of the land area is plateau, gorgeous hills and mountains, respectively. In the study zone, about $65 \%$ of the land is put under different crops, $6 \%$ of the land area covered by natural and manmade forest, $19 \%$ occupied by grassland for grazing animals and the remaining $10 \%$ of the land used for other purposes.

A total of four unions and 104 primary cooperatives are engaged in the provision of agricultural inputs (such as fertilizers, pesticides and improved seeds), agricultural marketing services and modern crop storage. Out of these, 23 primary cooperatives are organized to collect milk from farmers and supply to the market or to union or milk processors. North Shewa zone is well-known for its livestock resources. Cattle $(1,676,748)$, sheep $(992,486)$, goats $(314,954)$, horses $(90,476)$, mules $(11,547)$, and donkeys $(245,529)$ constitute major livestock species and about 902,269 chickens are found in the zone. In 2019, 173,388 (158,948 traditional, 18, 822 semi-modern and 6,481 modern) beehives were in use by the farmers in the zone (NSZPEDO, 2019).

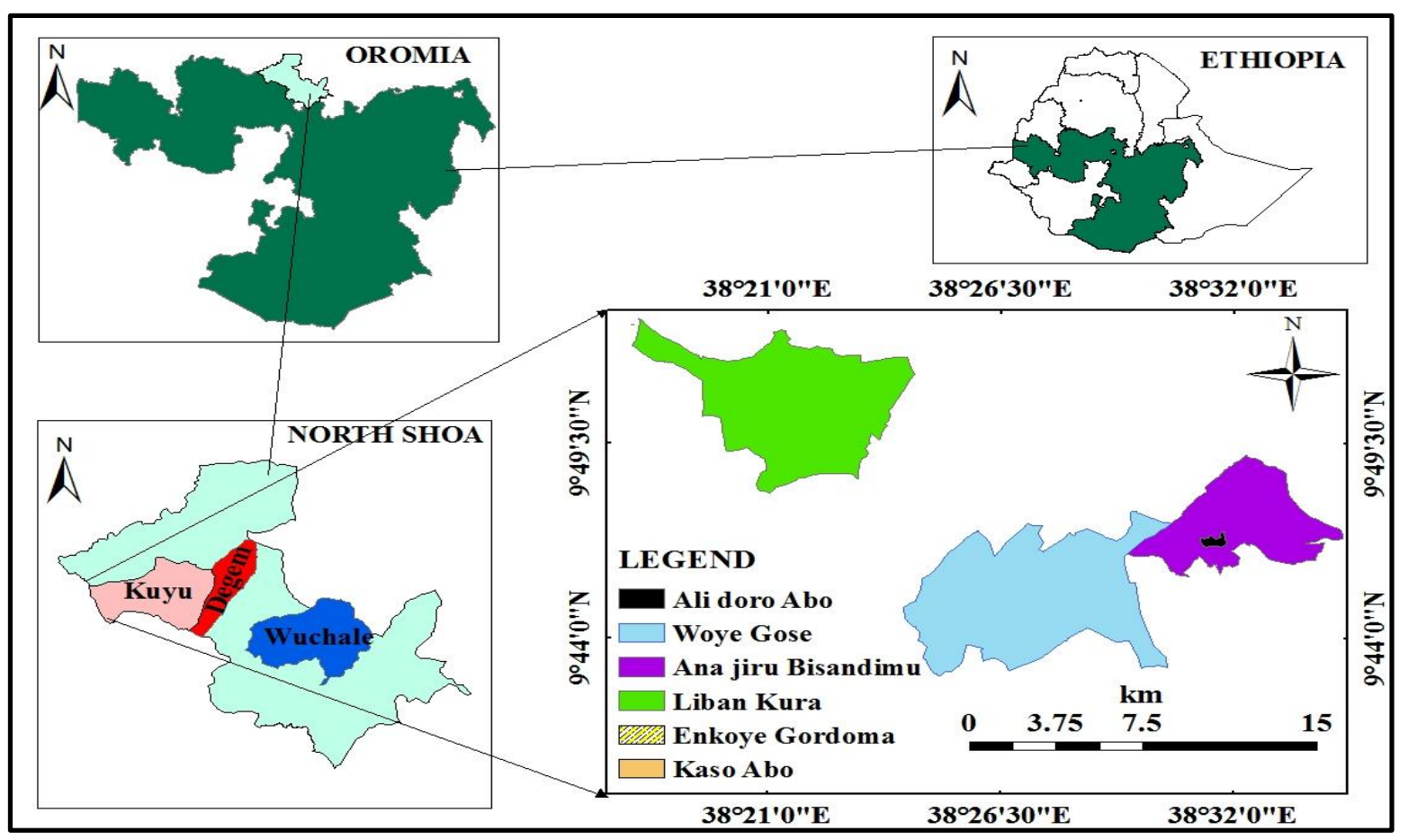

Figure 1. Map of the study area

\subsection{Data}

In this study, both primary and secondary data were collected based on the nature, importance, and availability of data to address the research questions. Primary data includes demographic, institutional, income, resource availability, costs and other factors in the study area. Primary data were gathered using key informants interviews, focus group discussions, personal observations and household surveys. The following procedure was used in the data collection process. First, before starting the actual data collection, some preliminary information about the overall dairy farming system in the zone was gathered through an informal survey. The resulting information has been used as input in the construction of a semi-structured questionnaire. Secondly, pre-testing of the semi-structured questionnaire was conducted so that the appropriate refinements and modification of the 
questionnaire can be made. Thirdly, enumerators were carefully recruited and trained. Finally, the collection of data was undertaken as per the work plan.

Secondary data were gathered from relevant sources including government organizations like North Shewa Zone Planning and Economic Development Office which summarizes all activities of different offices performed in the zone. Similarly, information from privately owned enterprises like milk processing industries, animal feed shops, etc., NGOs and other relevant sources like bulletins, websites, etc. were accessed and used.

\subsection{Sampling Design}

The survey was administered on sample households that are drawn using a multistage stratified random sampling technique. Our target population is dairy producers in North Shewa zone who has at least one crossbred cow as a means of inclusion into the study. In the first stage, three districts out of thirteen districts in the zone were chosen based on their milk production potential and participation in milk markets. In the second stage, two farmers' associations (kebeles) per each district were randomly selected. In the third stage, dairy-producing households were stratified in each kebele as participants and non-participants in dairy contract farming. Finally, representative sample households were selected using probability proportional to size (PPS).

To determine the desired sample size, a formula developed by Cochran (1963) was used.

$$
\mathrm{n}=\frac{Z^{2} * p * q}{e^{2}}=\frac{1.96^{2}(0.5)(0.5)}{(0.05)^{2}} \approx 384
$$

Where $\mathrm{n}$ is the sample size to be drawn, $\mathrm{z}$ is the desired confidence level (the value corresponding to the 95 percent level of confidence i.e. 1.96), e is the desired level of precision (maximum margin of error, i.e. 5\%), and $\mathrm{p}$ is the estimated proportion (degree of variability) of an attribute that is present in the population. Additionally, 40 respondents $(10.42 \%)$ were kept as a reserve considering possible errors, omissions, and non-response rates. Accordingly, 424 sample dairy producing households were included in the study. Out of this, about $55 \%$ of the households are non-participants in the contract farming with a view to achieving the objectives of the study.

\subsection{Methods of Data Analysis}

Although there are binary probit and logit models that are standard discrete choice models for estimating probability, the results attained by both models are not very different in terms of binary outcomes. The only difference in the two models is the specification of probability as a function of regressors. Hence, the choice of model depends more on the preference and the purpose of post estimation calculations.

$$
P=\operatorname{Pr}[Y i=1 \mid x i j]=\Lambda\left(x i^{\prime} \beta\right)=\frac{\exp \left(\alpha+\sum_{i=1}^{j} \beta i x i\right)}{1+\exp \left(\alpha+\sum_{i=1}^{j} \beta i x i\right)}=\frac{e^{x i \beta i}}{1+e^{x i \mathrm{~B} i}}
$$

Where, $p_{i}, 0<p_{i}<1$. This is the logistic cumulative distribution function, with

$$
\Lambda_{(Z)}=\frac{e^{Z}}{1+e^{z}}=\frac{1}{\left(1+e^{-Z}\right)}
$$

Maximum likelihood estimation leads to the estimation of parameter $\beta_{i}$ for $i=1, . ., j$. In the logit model, the marginal effects can be easily obtained from the estimated coefficients, since,

$$
\frac{\partial P_{i}}{\partial X_{i j}}=\frac{P_{i}}{\left(1-P_{i}\right)^{\beta_{i}}}
$$

Where, $P_{i}=\wedge_{i}=\wedge\left(X_{i} \beta\right)$

When $P_{i}$ denotes i- ${ }^{\text {th }}$ household's probability of participation, $\left(1-P_{i}\right)$ denotes the probability of no participation, so that $\frac{P_{i}}{1-P_{i}}$ can be defined as an odds ratio which measures relative probability of participation $\left(\mathrm{Y}_{\mathrm{i}}=1\right)$ to non-participation $\left(\mathrm{Y}_{\mathrm{i}}=0\right) . \mathrm{X}_{\mathrm{ij}}$ denotes the socio-economic characteristics of the $\mathrm{i}^{\text {th }}$ household.

In the logit model, 


$$
\frac{P_{i}}{1-P_{i}}=\exp \left(X_{i} \beta\right)
$$

So that the log-odds ratio which is linear in the regressors can be defined by;

$$
\ln \frac{P_{i}}{1-P_{i}}=\exp \left(X_{i} \beta\right)
$$

Participation status of sample households in the dairy contract farming during the 2018/19 production year was considered as the dependent variable. In the present study, the explanatory or the matching variables are age, education, amount of credit, sex, involvement in equib, time taken to milk collection center, access to market information, household size, type of the dairy cow breed kept by the household, access to training, perception of price uncertainty, frequency of extension contact, off/non-farm income and livestock holdings (TLU) were hypothesized to affect participation in dairy contract farming based on a review of relevant literature.

\section{Results and Discussions}

This part of the article presents results and discussions of the findings. Specifically, the first section reports results of the descriptive statistics. Whereas, the second section presents, logistic regression model results.

\subsection{Socio-economic and Demographic Characteristics of the Sample Households}

Table 1 and 2 provides summary statistics of the sampled households by participation in contract farming. Out of the total sample households, $45 \%$ were participating in milk contract farming while $55 \%$ were not participating in the scheme. In the study area, contract farming involves both oral and written agreements. Results of descriptive analysis are presented hereunder.

\begin{tabular}{|c|c|c|c|c|c|c|c|}
\hline \multirow[t]{2}{*}{ Variables } & \multicolumn{2}{|c|}{$\begin{array}{l}\text { Total Sample } \\
(\mathrm{n}=424)\end{array}$} & \multicolumn{2}{|c|}{$\begin{array}{l}\text { Non-participants } \\
(\mathrm{N}=232)\end{array}$} & \multicolumn{2}{|c|}{$\begin{array}{l}\text { Participants } \\
(\mathrm{N}=192)\end{array}$} & \multirow[t]{2}{*}{ t-test } \\
\hline & Mean & Std. Dev. & Mean & Std. Dev. & Mean & Std. Dev. & \\
\hline Age & 41.2 & 10.6 & 40.3 & 9.2 & 42.2 & 12.1 & $-1.78 *$ \\
\hline Education & 12.9 & 4.82 & 12.74 & 5.03 & 13.12 & 4.58 & -0.78 \\
\hline Household size & 6.17 & 1.59 & 6.16 & 1.64 & 6.17 & 1.56 & -0.085 \\
\hline Credit & 1671.7 & 1361.5 & 1598.5 & 1329.4 & 1760.2 & 1397.7 & -1.22 \\
\hline Time taken to MCC & 0.83 & 0.412 & 0.925 & 0.467 & 0.72 & 0.29 & $5.39 * * *$ \\
\hline Extension & 1.90 & 0.617 & 1.89 & 0.632 & 1.92 & 0.599 & -0.405 \\
\hline TLU & 20.87 & 5.39 & 20.63 & 5.58 & 21.16 & 5.16 & -1.03 \\
\hline Off/non-farm income & 8338.8 & 5366.4 & 8372.9 & 6010.7 & 8297.6 & 4481.1 & 0.143 \\
\hline
\end{tabular}

Table 1. Descriptive statistics of continuous variables $(n=424)$

Note: $* * *$ and $*$ represent significance at $1 \%$ and $10 \%$ probability levels, respectively

Source: Own computation result based on survey data (2019)

The average age of the households for the entire sample was 41.2 years. The mean age of participants and non-participants in dairy contract farming were 42.2 and 40.3 years, respectively. Whereas, the average time taken to the milk collection centers (points) were 0.72 for participants and 0.925 for non-participants from a residence in walking hours, respectively. The t-test result shows that there is a statistically significant mean difference between the two groups in terms of the age of the household heads and time taken to milk collection centers at a $10 \%$ and $1 \%$ probability level, respectively. Likewise, the average school attended for non-participants household head was 12.74 while the corresponding figure stands at 13.12 for participants. The results in Table 1 also show that the average family size for non-participants and participants were 6.16 and 6.17 persons, respectively. Furthermore, the average amount of credit utilized by non-participating households was 1,598.5 Birr and 1,760.2 Birr for contract participating households. Of the total sampled households the average incomes generated from off/non-farm income were 6, 010.7 and 8,297.6 birr respectively (Table 1).

In the 2018/19 production year, the mean frequency of extension contact for non-participants and participants were 1.89 and 1.92 days per week in the study area, respectively. In order to standardize the livestock holdings of the sample households, TLU was calculated based on conversion factors. Based on TLU measure, the average livestock holding per households was 20.87 for sample households. The average livestock holding for non-participants and participants in the study area was 20.63 and 21.16 TLU, respectively (Table 1). 
Table 2. Summary statistics of dummy variables $(n=424)$

\begin{tabular}{|c|c|c|c|c|c|c|c|c|}
\hline \multirow[t]{2}{*}{ Variables } & \multirow[t]{2}{*}{ Responses } & \multicolumn{2}{|c|}{$\begin{array}{l}\text { Total Sample } \\
(\mathrm{n}=424)\end{array}$} & \multicolumn{2}{|c|}{$\begin{array}{l}\text { Non-participants } \\
(\mathrm{N}=232)\end{array}$} & \multicolumn{2}{|c|}{$\begin{array}{l}\text { Participants } \\
(\mathrm{N}=192)\end{array}$} & \multirow[t]{2}{*}{$\begin{array}{l}\text { Chi2 } \\
\text { value }\end{array}$} \\
\hline & & Freq. & $\%$ & Freq. & $\%$ & Freq. & $\%$ & \\
\hline \multirow[t]{2}{*}{ Sex } & Male headed (1) & 332 & 78.3 & 172 & 51.8 & 160 & 48.2 & $5.22 * *$ \\
\hline & Female headed $(0)$ & 92 & 21.7 & 60 & 65.2 & 32 & 34.8 & \\
\hline \multirow[t]{2}{*}{ Typebreed } & Crossbred only (1) & 172 & 40.6 & 102 & 59.3 & 70 & 40.7 & 2.46 \\
\hline & Others $(0)$ & 252 & 59.4 & 130 & 51.6 & 122 & 48.4 & \\
\hline \multirow[t]{2}{*}{ MarketInfo } & Yes (1) & 222 & 52.4 & 115 & 51.8 & 107 & 48.2 & 1.59 \\
\hline & No (0) & 202 & 47.6 & 117 & 57.9 & 85 & 42.1 & \\
\hline \multirow[t]{2}{*}{ Equib } & Yes (1) & 212 & 50 & 115 & 54.2 & 97 & 45.8 & 0.038 \\
\hline & No (0) & 212 & 50 & 117 & 55.2 & 95 & 44.8 & \\
\hline \multirow{4}{*}{$\begin{array}{l}\text { Perception of } \\
\text { price uncertainty } \\
\text { Training }\end{array}$} & Uncertain (1) & 219 & 51.7 & 101 & 46.1 & 118 & 53.9 & $13.52 * * *$ \\
\hline & Others $(0)$ & 205 & 48.3 & 131 & 63.9 & 74 & 36.1 & \\
\hline & Yes (1) & 339 & 80 & 169 & 49.9 & 170 & 50.1 & $16.15 * * *$ \\
\hline & No $(0)$ & 85 & 20 & 63 & 74.1 & 22 & 25.9 & \\
\hline
\end{tabular}

Note: $* * *$ and $* *$ represent significance at $1 \%$ and $5 \%$ probability levels, respectively

Source: Own computation result based on survey data (2019)

During the $2018 / 19$ production year, $78.3 \%$ of the sampled households were male-headed in the study area. Only $21.7 \%$ of the sampled female headed households did participate in dairy contract farming and this number indicates that there is low participation of females in milk contract farming in the study area. The binary coded sex of the household head has chi2 result of 5.22, which indicated that there is a significant difference between contract farmers and non-contract farmers in terms of sex of the households head at 5\% probability level. Likewise, $40.6 \%$ smallholder farmers in the study area own only crossbred cows for milk production and of these, $40.7 \%$ were participants in dairy contract farming during the survey time (Table 2).

Access to market information enables producers to search for and associate the information available for different market channels to manage the cost benefit analysis related to dairy production in the study area. Of the total sampled households, $52.4 \%$ has access to market information and of these $48.2 \%$ participated in dairy contract farming. Again, equib involvement helps households to accumulate more money for further investment that enhances participation in dairy contract farming. Of the total sampled households, $50 \%$ of the milk producing farmers involved in equib. At the time of the survey, $45.8 \%$ of those who involved in equib had participated in dairy contract faming. The binary coded perception of price uncertainty and access to training has chi2 result of 13.51 and 16.15 , respectively. That means there is a significant difference between contract farmers and non-contract farmers in terms of perception about milk price uncertainty in the local market and access to training at $1 \%$ probability level, respectively. In the 2018/19 production year, 53.9\% of the households are uncertain about the price of milk in the local market and finally, chooses to participate in dairy contract farming. Likewise, of the total sampled households, $80 \%$ has an access to training in dairy production and management in the study area.

\subsection{Logistic Regression Results}

The estimates of the binary logistic regression are shown in Table 3. In general, the logistic regression model fits the data well. The Wald chi-square test statistic was statistically significant at $1 \%$ probability level indicating that the hypothesis that the model has no explanatory power of the model was strongly rejected. Table 3 below shows the MLE estimates of the logistic regression for participation variables. 
Table 3. The logistic regression estimate of participation in dairy contract farming

\begin{tabular}{lll}
\hline Independent variables & Odds Ratio & Std. Err \\
\hline Age of the household head & $1.022^{* *}$ & 0.01 \\
Education of the household head & 1.009 & 0.024 \\
Amount of credit utilized & 1.000 & 0.00008 \\
Sex of the household head & $1.794^{* *}$ & 0.501 \\
Equib involvement & 1.067 & 0.237 \\
Time taken to a milk collection center & $0.078^{* * *}$ & 0.032 \\
Market information & 1.37 & 0.303 \\
Household size & 1.021 & 0.073 \\
Type of breed & 1.42 & 0.322 \\
Training & $2.85^{* * *}$ & 0.847 \\
Perception of price uncertainty & $2.249^{* * *}$ & 0.500 \\
Extension & $2.374^{* * *}$ & 0.565 \\
TLU & 1.006 & 0.02 \\
Total off/non-farm income & 1.000 & 0.00002 \\
Constant & $0.034^{* * *}$ & 0.034 \\
\hline LR chi2(14) = 93.74*** & & \\
Pseudo R2 = 0.1605 & & \\
Log likelihood = -245.134 & & \\
Observation = 424 & & \\
\hline
\end{tabular}

Note: $* * * * *$, represent significance at $1 \%$, and $5 \%$ probability levels, respectively

Source: Own computation result based on survey data (2019)

Age of the household head: Age of the household head is found to be significantly and positively affect participation in milk contract farming at 5\% probability level. Results also show that the odds ratio in favor of participation increases by 1.022 as the age of the household head increases by one year in the study area. Dairying like any other agricultural activity needs knowledge, skill and above all lifelong vicarious learning helps farmers to decide to participate in dairy contract farming. The result is consistent with what had been reported by D'Silva et al. (2009) and Leykun and Jema (2014).

Sex of the household head: Sex of the household head appears to affect participation in dairy contract farming positively and significantly at a 5\% probability level (Table 3 ). The odds ratio in favor of participation in milk contract farming increases by 1.794 as the sex of the household shift from a female headed to male headed one. The possible explanation is that male headed households do have better opportunities of discussing with milk collectors, signing contract, collecting sales money, making negotiations, etc. one can also argue that male-headed households do often have better practical experiences in the external affairs of the household compared to others. Contrary to this, female-headed households are usually occupied with core domestic activities and have little time on activities outside home management which might have led them to low participation in dairy contract farming in the study area. This result is consistent with the findings of Anh et al. (2019).

Time taken to a milk collection center: It is the time taken from the residence of smallholder farmers to the milk collection center. Distance to milk collection center significantly and negatively affects participation in contract farming at $1 \%$ probability level. The odds ratio of participation in dairy contract farming decreases by 0.078 as milk-producing households residence increases by one walking hour from milk collection centers in the study area (Table 3). The result confirms that the nearer the household resides to a milk collection center, the higher the probability that he/she participates in dairy contract farming. This result is consistent with the findings of Ntaganira et al. (2017).

Training on dairy farming: It is the training given to farmers on some improved dairy husbandry practices or protecting animals from disease, etc. during the 2018/19 production year. It is a dummy variable that takes a value of one if a farmer gets any form of training; otherwise zero. Participation in training significantly and positively affects participation in contract farming at $1 \%$ probability level. The odds ratio in favor of participation in milk contract farming increases by 2.85 as the household got additional training chances in the study area. Training given to smallholder farmers has great effect on milk production which requires intensive knowledge and higher managerial skills and also to create a sustainable market in the study area. Ntaganira et al. (2017) reported that training in forage management affect participation in dairy contract farming positively and 
significantly.

Perception about price uncertainty: It is a variable included into the model to examine if smallholder milk producing farmers choose contract farming when they are uncertain about spot market prices prior to the supply of milk in the study area. Perception about price uncertainty significantly and positively affects participation in dairy contract farming at $1 \%$ probability level (Table 3 ). That means the odds ratio in favor of participation in dairy contract farming increases by 2.387 if the household head perceived the price of milk in the spot (local) market is uncertain. This result is consistent with the findings of Seerp (2018).

Extension contact: It is the frequency of contact made to visit smallholder farmers per week in the study area. Some farmers visit extension agents more frequently while others visit rarely. Frequency of extension contact significantly and positively affects participation in contract farming at $1 \%$ probability level. The odds ratio of participation in dairy contract farming increases by 2.374 as milk-producing households visited by extension agents increases by one in the study area. This result is consistent with the findings of Babatunde et al., (2007) which confirm that, extension visits will help to reinforce the message and enhance the accuracy of implementation of the technology packages in Kwara State, North Central Nigeria.

\section{Conclusion and Recommendations}

Contract farming enhances the productivity of smallholder farmers by introducing improved farming practices through the provision of inputs, credit, extension services, and other support services. The study was conducted in North Shewa Zone of Oromia National Regional State, Ethiopia by surveying 424 farmers (192 participants and 232 non-participants households) to identify factors affecting participation of milk-producing households in dairy contract farming. The results from logistic regression showed that age and sex of the respondents, perception of price uncertainty, access to training and frequency of extension contact affect participation in dairy contract farming significantly and positively. Finally, distance to milk collection centers influenced the participation in contract farming significantly and negatively.

Therefore, the following important policy recommendations are given based on the results of the study. The findings suggest that the need to encourage young farmers, female-headed households, increasing frequency of extension contact, creating access for training, decentralization of milk collection centers for smallholder farmers with a reasonable cost for collectors to create a win-win profitable market environment and contract farming reduces perceived price uncertainty faced by smallholder farmers from the spot market through creating guaranteed milk price in the study area.

\section{Acknowledgments}

This publication was made possible by the financial support provided in part by the Ethiopian Ministry of Education, Salale and Haramaya University. All views, interpretations, recommendations, and conclusions expressed in this paper are those of the authors and not necessarily those of the supporting or collaborating institutions.

\section{References}

Adjognon, S. (2012). Contract farming as a tool for poverty reduction in Africa. Research to practice policy briefs ISID, 4. Retrieved from http://drupalnode1.ncs.mcgill.ca/isid/files/isid/pb_2012_04_adjognon.pdf

AGP-LMD (Agricultural Growth Program - Livestock Market Development), (2013b). Value chain analysis for Ethiopia: meat and live animals, hides, skins and leather, and dairy. Addis Ababa, Ethiopia.

Anh, H. N., Wolfgang, B., Ngo, T. T., Do, T. N., \& Nguyen, V. M. (2019). Smallholders' Preferences for Different Contract Farming Models: Empirical Evidence from Sustainable Certified Coffee Production in Vietnam. Journal of Sustainability, 11, 1-26. https://doi.org/10.3390/su11143799

Assefa, B. (2018). Factors Affecting Milk and Milk Product Export by Ethiopia. A Review of Article. Approach in Poultry, Dairy and Veterinary Sciences, 6(3), 1-6

Babatunde, R. O., Omotesho, O. A., \& Sholotan, O. S. (2007). Socio-economic characteristics and food security statuse of farming households in Kwara State, North Central Nigeria. Pakistan Journal of Nutrition, 6(1), 49-58. https://doi.org/10.3923/pjn.2007.49.58

Birhanu, M. L. (2016). Gender, intra-household dynamics and smallholder milk market participation in Ethiopia. Ph.D. Dissertation, Radboud University Nijmegen, and the Netherlands.

Birthal, P. S., Jha, A. K., Tiongco, M. M., \& Narrod, C. (2008). Improving Farm-to-Market Linkages through Contract Farming: A Case Study of Smallholder Dairying in India. Discussion Paper 00814. International 
Food Policy Research Institute. Washington, D.C.

Birthal, P. S., Joshi, P. K., \& Ashok, G. (2005). Vertical coordination in high-value food commodities: implications for smallholders, markets, trade and institutions division Discussion Paper No. 85. International Food Policy Research Institute, Washington, D.C., U.S.A.

Bolwig, S. (2012). Poverty and gender effects of smallholder organic contract farming in Uganda. USSP Working Paper; No. 8. International Food Policy Research Institute, Roskilde, Denmark.

Brüntrup, M., \& Peltzer, R. (2006). Outgrowers - A key to the development of rural areas in Sub Saharan Africa and to poverty reduction. The DEG / DIE Workshop, 2006. Retrieved from http://www.diegdi.de/uploads/media/Outgrowers_sub-saharan-african_rural_areas.pdf.

Cochran, W. G. (1963). Sampling Techniques, 2nd Edition. John Wiley and Sons, Inc., New York.

Costales, A., Son, N. T., Lapar, M. L., \& Tioncgo, M. (2008). Determinants of participation in contract farming in pig production in Northern Viet Nam. Pro-Poor Livestock Policy Initiative, a living from Livestock Research Report. Retrieved from http://www.fao.org/3/a-bp276e.pdf.

D’Silva, J. L., Hayrol, A. M. Sh., Jegak U., \& Bahaman, A. S. (2009). A Review of Contract Farming and Factors that Impinge Youths Acceptance to Contract Farming. European Journal of Social Sciences, 11(2), $1-11$.

Gemechu, M., Jema, H., Belaineh, L., \& Mengistu, K. (2017). Impact of participation in vegetables' contract farming on household's income in the central rift valley of Ethiopia. American Journal of Rural Development, 5(4), 90-96. https://doi.org/10.12691/ajrd-5-4-1

Hanisch, M., \& Rommel, J. (2012). Support for Farmers' Cooperatives; Case Study Report. Producer Organizations in European Dairy Farming. Wageningen: Wageningen UR.

Holloway, G., \& Ehui, S. (2002). Expanding market participation among smallholder livestock producers: a collection of studies employing Gibbs sampling and data from the Ethiopian highlands. Socioeconomics and policy research working Paper 48, International Livestock Research Institute, Nairobi.

Holtland, G. (2017). Contract farming in Ethiopia: Concept and practice. Arnhem, The Netherlands: AgriProFocus.

Leykun, D. B., \& Jemma, H. (2014). Econometric analysis of factors affecting market participation of smallholder farming in Central Ethiopia. Journal of Agricultural Economics, Extension and Rural Development, 2(6), 94-104.

MacDonald, J., \& Korb, P. (2011). Agricultural Contracting Update: Contracts in 2008. EIB-72. U.S. Dept. of Agriculture, Economic Research Service, February 2011. https://doi.org/10.2139/ssrn.2114442

Makoni, N., Mwai, R., Redda, T., Zijpp, A. V., \& Lee, J. V. (2013). White Gold; Opportunities for Dairy Sector Development Collaboration in East Africa. Centre for Development Innovation, Wageningen UR (University \& Research centre). CDI report CDI-14-006. Wageningen.

NSZPEDO (North Showa Zone of Planning and Economic Development Office), (2019). Socio economic profile of North Showa Zone, Selale. Unpublished material.

Ntaganira, E., Jaya, Sh., Robert, Mb., Mbabazi, Mb., \& Kanuma, T. (2017). Determinants of farming among participation in contract small holder dairy farmers in Rwanda. International Journal of Thesis Projects and Dissertations, 5(3), 11-19.

Oltenacu, P. A., \& Broom, D. M. (2010). The impact of genetic selection for increased milk yield on the welfare of dairy cattle. Animal Welfare, 19, 39-49.

Rehber, E. (2019). Contract Farming in Practice: An Overview. Zwick Center for Food and Resource Policy Research Report No.7, Connecticut, USA.

Seerp, W. (2018). Income Intervention Quick Scan: Outgrower Schemes and Contract farming; Farmer Income Lab Intervention Quick Scan. Wageningen Centre for Development Innovation, Wageningen University \& Research. Report WCDI-18-032. Wageningen.

Shapiro, B. I., Getachew, G., Solomon, D., Asfaw, N., Kidus, N., Gezahegn, A., \& Henok, M. (2017). Ethiopia livestock sector analysis. ILRI Project Report. Nairobi, Kenya: International Livestock Research Institute (ILRI).

SNV (Netherlands Development Organization), (2010). Ethiopia and target business consultants PLC, Inventory 
of Dairy Policy, Addis Ababa, Ethiopia.

UNCTAD (United Nations Conference on Trade and Development), (2009). World Investment Report, Geneva. UNCTAD (United Nations Conference on Trade and Development), (2011). World Investment Report, Geneva.

\section{Copyrights}

Copyright for this article is retained by the author(s), with first publication rights granted to the journal.

This is an open-access article distributed under the terms and conditions of the Creative Commons Attribution license (http://creativecommons.org/licenses/by/3.0/). 